\title{
IN DEFENSE OF THE UNAUTHORIZED USE: RECENT DEVELOPMENTS IN DEFENDING COPYRIGHT INFRINGEMENT
}

\author{
ThOmas R. Leavens*
}

One of the principal circumstances of our condition is that we are at times compelled by events, need or our weak nature to borrow from the expression of others. ${ }^{1}$ Literary theft has never been widely or legitimately supported, yet the economic protection afforded authors has always been balanced and limited by the societal interest in permitting certain borrowings. The ongoing conflict in copyright principles was well expressed in the Foreword to a similar symposium of this publication over twenty-five years ago:

Certainly in our democratic society it can hardly be questioned that literary and artistic products should be given enough legal protection so that private enterprise, encouraged by the financial rewards made possible by such protection, will be willing to create, develop, and use them. We do not wish our writers, artists, and composers to be financially dependent solely or mainly on state subsidies or private philanthropy. On the other hand, an essential element of our democratic society is the transmission, development, and use of intellectual products in the freest possible manner and with the fewest possible restraints. For this reason, we look askance at state censorship or control in these areas. However, such restraints may be no less objectionable if imposed by authors, artists, composers, or producers for their private gains rather than by the state on moral or political grounds. Consequently, those who demand protected rights in intellectual products must be willing also to accept correlative duties and responsibilities. The law must not permit the protections given here to turn into barriers walling off part or all of our society from the use and enjoyment of these literary and artistic products at a cost within their reach. ${ }^{2}$

This article examines some recent developments in the defense of copyright

Copyright $C 1982$ by Law and Contemporary Problems

*Attorney, Pattishall, McAuliffe \& Hofstetter, Chicago, Illinois, specializing in trademarks, copyrights and entertainment law.

1. In truth, in literature, in science and in art, there are, and can be, few, if any, things which, in an abstract sense, are strictly new and original throughout. Every book in literature, science and art, borrows and must necessarily borrow, and use much which was well known and used before. . . . If no book could be the subject of copyright which was not new and original in the elements of which it is composed, there could be no ground for any copyright in modern times, and we would be obliged to ascend very high, even in antiquity, to find a work entitled to such eminence. Virgil borrowed much from Homer; Bacon drew from earlier as well as contemporary minds; Coke exhausted all the known learning of his profession, and even Shakespeare and Milton . . . would be found to have gathered much from the abundant stores of current knowledge and classical studies in their days. . . . In truth every author of a book has a copyright in the plan, arrangment and combination of his materials, and in his mode of illustrating his subject, if it be new and original in its substance.

Emerson v. Davies, 8 F. Cas. 615, 619 (C.C.D. Mass. 1845) (No. 4436), quoted in M. NIMMER, 1 NIMMER ON COPYRIGHT $\S 3.01$, at 3-2, 3-3 (1978) [hereinafter cited as NimmER]. See also Decorative Aides Corp. v. Staple Sewing Aides Corp., 497 F. Supp. 154, 157 (S.D.N.Y. 1980); Alexander v. Haley, 460 F. Supp. 40 (S.D.N.Y. 1978)

2. Kramer, Foreword, 19 LaW \& ConTEMP. Probs. 139, 140 (1954). 
infringement claims concerning admitted borrowings. ${ }^{3}$ Defenses included are de minimus use, fair use (including parody) and the first amendment. The defenses are often pled in the alternative and, in the foregoing ascending order, excuse an increasing appropriation from a copyrighted work. De minimus use involves an insubstantial taking which fails to rise to the level of an infringement. Fair use involves what may be a substantial taking excused on equitable grounds. The first amendment defense involves conflicting political and social values to which copyright interests are thought to yield. There are few, if any, per se rules applicable to these defenses. Each case must be decided on its own terms after consideration of several difficult and elusive factors that reflect differing social values. The absence of clear lines in this area and the changing balance courts apply to their judgments often result in decisions that are difficult to reconcile. Nevertheless, general principles can be extracted from the cases that, when understood, will serve well those counseling authors and producers on permissible sources for and the content of artistic property.

\section{I}

\section{De Minimus}

The de minimus defense involves an essential element of a copyright infringement action: substantial similarity between a copyrighted work and an accused work. ${ }^{4}$ Unless such a similarity can be proved, together with access to the copied work, the infringement claim will fail.

The de minimus defense was rejected in the recent case of Elsmere Music, Inc. $v$. National Broadcasting Co. ${ }^{5}$ The plaintiff's "I love New York" advertising jingle, extensively used to promote both the state and city of New York, was featured in an NBC Saturday Night Live comedy sketch to portray an attempt by the biblical city of Sodom to create a more positive image of the city for tourists. The jingle's "I love New York" chorus was sung during the sketch three or four times as "I love Sodom." The district court found that NBC's use, although slight when considered as a percentage of plaintiff's total composition, was nevertheless substantial because it constituted the "heart of the composition,"6 and was easily recognizable as having been taken from the copyrighted work.

The de minimus defense was raised in an interesting manner in Hoehling $v$. Universal City Studios, Inc. ${ }^{7}$ Hoehling, the author of a book about the destruction of the Hindenberg dirigible in 1937, sued to enjoin a subsequent book and movie about the same topic. He claimed that the essential part of his work in which an alleged

3. The defenses of a license or assignment from the copyright owner, joint ownership of the work, jurisdictional defects, limitations, laches, res judicata, estoppel, and abandonment are discussed generally in 3 NimMER, supra note 1 , at $\S 13$. The statutory defense of good faith reliance upon an erroneous copyright notice found at 17 U.S.C. 406(a) (Supp. III 1979) is carefully discussed in Quinto v. Legal Times of Washington, Inc., 506 F. Supp. 554 (D.D.C. 1981).

4. See generally 3 NimMER, supra note $1, \S 13.03[\mathrm{~A}]$.

5. 482 F. Supp. 741 (S.D.N.Y.), affd, 623 F.2d 252 (2d Cir. 1980).

6. Id. at 744. See also H.C. Wainwright \& Co. v. Wall Street Transcript Corp., 418 F. Supp. 620,625 (S.D.N.Y. 1976), affd, 558 F.2d 91 (2d Cir. 1977).

7. 618 F.2d 972 (2d Cir.), cert. denied, 449 U.S. 841 (1980). 
saboteur of the dirigible was revealed had been copied. The defendants defended successfully on the grounds that, with minor exceptions, the material copied from Hoehling's book was not copyrightable.

The Second Circuit's opinion, affirming defendants' summary judgment, dismissed the essential aspects of plaintiff's book as unprotectable. The court first stated its belief that theories interpreting an historical event were not copyrightable: "To avoid a chilling effect on authors who contemplate tackling an historical issue or event, broad latitude must be granted to subsequent authors who make use of historical subject matter, including theories or plots."8 Expressly disagreeing with other circuits, ${ }^{9}$ the court also held that the facts disclosed in Hoehling's book, although discovered through his original research, were in the public domain and free to be copied. Further, many similarities involved scenes a faire, that is, "incidents, characters or settings which are as a practical matter indispensable, or at least standard, in the treatment of a given topic."10 Thus these were noncopyrightable as a matter of law. Finally, the court recognized that, as in trademark cases, "[i]t is a fallacy to break the fagot stick by stick."11 The court found that notwithstanding the shared use of the separate noncopyrightable elements examined, each author had generally used his original expression to relate the familiar story of the Hindenburg.

The case illustrates, as stated by the court, that "[a]bsent wholesale usurpation of another's expression, claims of copyright infringement where works of history are at issue are rarely successful." 12 The opinion would have been strengthened had greater emphasis been given to the more basic argument available to the court: that the Copyright Act expressly exempts ideas and discoveries from the scope of copyright protection. ${ }^{13}$ Since the historian does not create facts but discovers them, ${ }^{14}$ his contribution lacks the originality necessary to render him an author in either the constitutional or statutory sense. ${ }^{15}$ The expression, ordering or selection of facts constitutes a work of authorship, ${ }^{16}$ but it is only this original contribution which is protectable, not the underlying information being expressed.

8. Id. at 978 .

9. See, e.g., Toksvig v. Bruce Publishing Corp., 181 F.2d 664, 667 (7th Cir. 1950); Miller v. Universal City Studios, Inc., 460 F. Supp. 984 (S.D. Fla. 1978).

10. 618 F.2d at 979. See also Schwartz v. Universal Pictures Co., 85 F. Supp. 270, 275-76 (S.D. Cal. 1945).

11. Joseph Schlitz Brewing Co. v. Houston Ice and Brewing Co., 250 U.S. 28, 29 (1919).

12. 618 F.2d at 974. See, e.g., Mount v. Viking Press, 204 U.S.P.Q. 353 (2d Cir. 1979).

13. 17 U.S.C. 102(b) (Supp. III 1979). This argument was given proper emphasis in Suid v. Newsweek Magazine, 503 F. Supp. 146 (D.C. 1980), which involved the reprinting of public domain material about John Wayne.

14. International News Serv. v. Associated Press, 248 U.S. 215, 234 (1918).

15. 1 Nimmer, supra note $1, \S 2.11$ [A]. The case of Rubin v. Boston Magazine Co., 645 F.2d 80 (1st Cir. 1981), decided under the 1909 Act, properly distinguished between unprotectable theories discovered by a behavioral scientist and his subsequent protectable expression and use of those theories in a questionnaire.

16. 17 U.S.C. § 103 (Supp. III 1979); Chicago Record-Herald Co. v. Tribune Ass'n, 275 F.2d 797 (7th Cir. 1921). For example, although statements transcribed for print by others are not copyrightable by the transcriber since he may not claim originality in such statements, Rokeach v. Avco Embassy Pictures Corp., 197 U.S.P.Q. 155, 161 (S.D.N.Y. 1978), the compilation of such statements is copyrightable. Quinto v. Legal Times of Washington, Inc., 506 F. Supp. 554 (D.D.C. 1981). 


\section{A. Background of Fair Use}

The fair use doctrine is a court-created, equitable ${ }^{17}$ defense that permits unconsented use of a copyrighted work on certain public policy grounds. ${ }^{18}$ The doctrine arises from the inherent conflict caused by the limited monopoly granted to copyright holders, the ultimate aim of which is "to stimulate artistic creativity for the general public good." 19 When the private interests of a copyright holder in controlling a work are inconsistent with the public welfare objectives of the Copyright Act or in conflict with the constitutionally supported public right of access to a work, ${ }^{20}$ the copyright owner's rights are subordinated under this doctrine. ${ }^{21}$

The fair use doctrine has a lengthy existence ${ }^{22}$ and has been characterized as the most troublesome issue in the whole law of copyright. ${ }^{23}$ The doctrine has been called both a privilege ${ }^{24}$ and a limitation. ${ }^{25}$ The term has been used to refer to both noninfringing ${ }^{26}$ and infringing, but excused, uses, ${ }^{27}$ and to both copyrightable $^{28}$ and noncopyrightable material. ${ }^{29}$ Fair use has been justified on the constitutional grounds that promotion of the progress of science and the useful arts is

17. Time, Inc. v. Bernard Geis Assocs., 293 F. Supp. 130, 144 (S.D.N.Y. 1968).

18. Fair use is also found in trademark law as a defense to the incontestability of a registered mark. 15 U.S.C. $§ 1115(b)(4)(1976)$. "The 'fair use' defense, in essence, forbids a trademark registrant to appropriate a descriptive term for his exclusive use and so prevent others from accurately describing a characteristic of their goods." Soweco, Inc. v. Shell Oil Co., 617 F.2d 1178, 1185 (5th Cir. 1980). See also M.B.H. Enterprises, Inc. v. WOKY, Inc., 633 F.2d 50, 54 (7th Cir. 1980); Frederick Warne \& Co., v. Book Sales Inc., 481 F. Supp. 1191, 1198 (S.D.N.Y. 1979); contra Dallas Cowboys Cheerleaders v. Pussycat Cinema, 467 F. Supp. 366, 375 (S.D.N.Y. 1979) ("In the trademark field there does not appear to be any welldefined doctrine of "fair use." ").

19. Twentieth Century Music Corp. v. Aiken, 422 U.S. 151, 156 (1975).

20. Red Lion Broadcasting Co. v. FCC, 395 U.S. 367, 390 (1969).

21. "[C]ourts in passing upon particular claims of infringement must occasionally subordinate the copyright holder's interest in a maximum financial return with the greater public interest in the development of art, science and industry." Berlin v. E.C. Publications, Inc., 329 F.2d 541, 544 (2d Cir.), cert. denied, 379 U.S. 822 (1964).

22. "The [fair use] doctrine first appeared back in 1841 in Folsom v. Marsh, 9 F. Cas. 342 (C.C.D.Mass. 1841), although the precise term 'fair use' did not make its appearance until 28 years later in Laurence v. Dana, 15 F. Cas. 26, 60 (C.D.Mass. 1869)." Triangle Publications, Inc., v. Knight-Ridder Newspapers, Inc., 626 F.2d 1171, 1174 (5th Cir. 1980).

23. Dellar v. Samuel Goldwyn, Inc., 104 F.2d 661, 662 (2d Cir. 1939).

24. "Fair use may be defined as a privilege in others than the owner of a copyright to use the copyrighted material in a reasonable manner without his consent, notwithstanding the monopoly granted to the owner by the copyright." H. BALL, THE LAW OF COPYRIGHT AND LITERARY Property $\$ 125$, at 260 (1944). See also Rosemont Enterprises v. Random House, Inc., 366 F.2d 303 (2d Cir. 1966), cert. denied, 385 U.S. 1009 (1967).

25. Register of Copyright, Report on the General Revision of the U.S. Copyright LaW 24-25 (Comm. Print 1961)(printed for the use of the House Committee on the Judiciary, 87th Cong., 1st Sess.).

26. Eisenschiml v. Fawcett Publications, Inc., 246 F.2d 598 (7th Cir. 1957), cert. denied, 355 U.S. 907 (1957).

27. Hoidredge v. Knight Publishing Corp., 214 F. Supp. 921 (S.D. Cal. 1963).

28. Loew's, Inc. v. Columbia Broadcasting Sys., Inc., 131 F. Supp. 165 (S.D. Cal. 1955), affd sub nom., Benny v. Loew's, Inc., 239 F.2d 532 (9th Cir. 1956), affd per curiam by an equally divided court sub nom., Columbia Broadcasting Sys., Inc. v. Loew's, Inc., 356 U.S. 43 (1958).

29. Bradbury v. Columbia Broadcasting Sys., Inc., 287 F.2d 478, 485 (9th Cir. 1961), cert. dismissed, 368 U.S. 801 (1961). 
sometimes best served by allowing limited exceptions to the copyright owner's limited monopoly. ${ }^{30}$ Custom or necessity also have excused substantial similarity. ${ }^{31}$ In some cases a copyright holder has been deemed to have given implied consent to the use of his work. ${ }^{32}$

Fair use was codified in the 1976 Copyright $\mathrm{Act}^{33}$ without definition, but with the intent of restating rather than "freezing or changing the doctrine",34 as judicially created. Since the doctrine has such a varied, inconsistent history, this lack of definition left many fair use questions unresolved. ${ }^{35}$

The current statutory fair use doctrine permits unconsented use "for purposes such as criticism, comment, news reporting, teaching ..., scholarship, or research."36 Four factors set forth in section 107 of the Act determine if a use is fair and thus not an infringement:

(1) the purpose and character of the use, including whether such use is of a commercial nature or is for non-profit educational purposes;

(2) the nature of the copyrighted work;

(3) the amount and substantiality of the portion used in relation to the copyrighted work as a whole; and,

(4) the effect of the use upon a potential market for or value of the copyrighted work. ${ }^{37}$

As prior to codification, these statutory factors are unfixed ${ }^{38}$ and meant to be evaluated in concert to maintain the flexibility of the fair use doctrine.

\section{B. The Effect Factor Problem}

Although the fair use factors have been given inconsistent emphasis historically, the single most important consideration is believed to be the degree of harm a subsequent user causes a work he has copied. ${ }^{39}$ The importance of the effect factor is grounded in the economic theory underlying copyright protection. Since the public welfare objectives of promoting science and the useful arts are believed

30. See, e.g., Berlin v. E.C. Publications, Inc., 329 F.2d 541 (2d Cir. 1964), cert. denied, 379 U.S. 822 (1964).

31. See, e.g., Decorative Aides Corp. v. Staple Sewing Aides Corp., 497 F. Supp. 154, 157 (S.D.N.Y. 1980); Alexander v. Haley, 460 F. Supp 40 (S.D.N.Y. 1978).

32. See, e.g., Mura v. Columbia Broadcasting Sys., Inc., 245 F. Supp 587 (S.D.N.Y. 1965); Karll v. Curtis Publishing Co., 39 F. Supp. 836, 837 (E.D. Wis. 1941).

33. 17 U.S.C. $\S 107$ (Supp. III 1979). The statutory language is in substantially the same form as adopted in copyright revision bills in 1964. See Time, Inc. v. Bernard Geis Assocs., 293 F. Supp. 130,145 (S.D.N.Y. 1968).

34. S. REP. No. 473, 94th Cong., 1st Sess. 62 (1975).

35. The Copyright Act states, for example, that "Fair use . . . is not an infringement of copyright." 17 U.S.C. $§ 107$ (Supp. III 1979). It would seem, therefore, that the fair use defense would properly be at issue upon the defendant's general denial that an infringement has occurred. The better practice, however, may be to raise the fair use defense as an affirmative defense. Fed. R. Civ. P. 8(c). Also, it is unclear whether the consistent use of the words "copyrighted work" in section 107 acts as a limitation on when a fair use may occur. See note 53 infra.

36. 17 U.S.C. $\$ 107$ (Supp. III 1979). These purposes are illustrative and not exhaustive. 17 U.S.C. $\S 101$, (Supp. III 1979).

37. 17 U.S.C. $\S 107$ (Supp. III 1979). These factors emerged from the case law. See, e.g., Mathews Conveyer Co. v. Palmer-Bee Co., 135 F.2d 73, 84-85 (6th Cir. 1943).

38. While the Copyright Act states each factor "shall", 17 U.S.C. $§ 107$ (Supp. III 1979), be considered by the court, the list is "illustrative and not limitative." Id. $\S 101$.

39. 3 NIMMER, supra note $1, \S 13.05[A][4]$. 
to be best achieved through economic incentives to authors, ${ }^{40}$ acts which adversely affect these incentives should be prevented. Conversely, uses without adverse economic impact theoretically harm neither the desired creative incentives nor the public welfare objectives and should therefore be permitted.

Professor Nimmer has suggested that the proper measure of the effect of an unauthorized use is whether the use supplants a valid use of the original work. ${ }^{41}$ If a use fulfills an actual or potential function of the original, that effect is assumed to be a disincentive to the author, and therefore constitutionally undesirable. If the use merely supplements the functions of the original work, however, it should be allowed, since other public welfare objectives may be achieved without loss to the author. This measure of a work's function does not require evidence of actual economic harm suffered by the copyright owner, but rather an examination of the nature of the original work and the purpose and character of the second use.

While the effect factor has been relied upon foremost by the courts, it has been perhaps least understood. The most troubling aspect of this reliance is the confusion which has developed from the failure to distinguish harm for purposes of the fair use defense from harm as an element in the determination of damages or the right to other infringement relief. This confusion is illustrated in the case of $W i l$ liams $\mathcal{E}^{2}$ Wilkins Co. $v$. United States. ${ }^{42}$ The Court of Claims determined that the plaintiff's failure "to prove its assumption of economic detriment, in the past or potentially for the future" 43 was important in the court's finding that library photocopying was fair use. The court stated:

This record simply does not show a serious adverse impact, either on plaintiff or on medical publishers generally, from the photocopying practices of the type of [defendant]. On the face of this record, we cannot mechanically assume such an effect, or hold that the amount of photo duplication proved here "must" lead to financial or economic harm. This is a matter of proof and plaintiff has not transformed its hypothetical assumption, by evidence, into a proven fact. ${ }^{44}$

This view of the fair use doctrine's effect factor has been widely and properly criticized. ${ }^{45}$ It is clear that a copyright owner should not be required to prove actual damages in order to overcome a fair use defense. To require a copyright owner to prove actual damages is inconsistent with the provisions of the Copyright Act. For example, the plaintiff's option to elect to receive statutory damages in lieu of his actual damages and the infringer's profits ${ }^{46}$ is statutory recognition that infringement, however nominal, causes actual harm to a copyright holder.

40. "The economic philosophy behind the clause empowering Congress to grant patents and copyrights is the conviction that encouragement of individual effort for personal gain is the best way to advance public welfare through the talents of authors and inventors in 'Science and useful Arts.' "Mazer v. Stein, 347 U.S. 201, 219 (1954).

41. 3 Nimmer, supra note $1, \S 13.05[B]$. See also S. REP. No. 473, 94th Cong., 1st Sess. 65 (1975). ("IA] use that supplants any part of the normal market for a copyrighted work would ordinarily be considered an infringement."); Hill v. Whalen \& Martell, Inc., 220 F. Supp. 359, 360 (S.D.N.Y. 1914).

42. 487 F.2d 1345 (1973), affd per curiam by an equally divided court, 420 U.S. 376 (1975).

43. Id. at 1359 .

44. Id. .

45. See, e.g., Nimmer, Photocopying and Record Piracy: of Dred Scott and Alice and Wonderland, 22 U.C.L.A.

L. Rev. 1052 (1975).

46. 17 U.S.C. $§ 504$ (c) (Supp. III 1979). 
Requiring proof of actual damages as an element of overcoming a fair use defense wrongfully erects a barrier to the owner's right to these statutory damages and in effect limits statutory damages to instances where infringement is undenied. ${ }^{47} \mathrm{~A}$ copyright owner's right to the other statutory remedies of an injunction, ${ }^{48}$ impoundment or destruction of infringing copies, ${ }^{49}$ and/or attorney fees and $\operatorname{costs}^{50}$ is also based on a finding of infringement, not harm. Even though an owner may not be able to prove actual damages, he should be entitled to have infringing copies of his work taken off the market.

Second, the speculative nature of copyright damages makes it unfair to require a showing of actual damages to overcome a fair use defense. Difficulty in determining actual damages for past conduct is compounded when the future effect of an unconsented use is computed. Since a court must examine both prior and potential uses to determine harm for purposes of the fair use defense, ${ }^{51}$ proving actual damages quickly becomes unreasonably difficult. Moreover, an objectionable use, although insignificant by itself, may join other unauthorized uses to have a substantial cumulative impact.

The tendency of the courts to give greatest weight to the effect factor also seems incorrect. First, application of any per se rule to the fair use doctrine erodes the flexibility courts should bring to any examination of a fair use situation. The fair use criteria are not frozen, nor should they be. To rely on one factor more than others tends to lessen the likelihood that a court will consider other statutory fair use factors or adopt new criteria when necessary.

Focus on the effect factor as an economic test is also misplaced, for it ignores the fact that certain noneconomic harms may cause disincentives greater than pecuniary loss. There are certain personal interests, the invasion of which may or may not be legally compensable, which are nevertheless given recognition in the control a copyright owner has over the exploitation of his work. ${ }^{52}$ The copyright owner's right of first publication ${ }^{53}$ provides the right to negotiate the terms of that

47. The Copyright Act provides for a reduction in the amount of statutory damages to a sum not less than $\$ 100.00$ when the court finds that an infringer "was not aware and had no reason to believe that his or her acts constituted an infringement of copyright." 17 U.S.C. $§ 504$ (c)(2) (Supp. III 1979). Fair use bars an award of statutory damages in two limited situations involving actual reliance on the fair use defense by employees of certain nonprofit educational institutions or public broadcasting entities. Id. .

48. 17 U.S.C. $§ 502$ (Supp. III 1979).

49. Id. $\$ 503$.

50. Id. $\$ 505$.

51. Id. $\S 107(4)$. See, e.g., Metro-Goldwyn-Mayer v. Showcase Atlanta Coop. Prod., 479 F. Supp. 351 (N.D. Ga. 1979).

52. But see Fortnightly Corp. v. United Artists Television, 392 U.S. 390, 393 (1968) ("The Copyright Act does not give a copyright holder control over all uses of his copyrighted work."); Eichel v. Marcin, 241 F. Supp. 404, 410 (S.D.N.Y. 1913).

53. Werckmeister v. American Lithographing Co., 134 F.2d 321,324 (2d Cir. 1904). The termination of common law copyright, 17 U.S.C. $\$ 301$ (Supp. III 1979), however, casts doubt on the continued validity of this concept. It is unclear whether prior to January 1, 1978, the fair use defense was available in actions for common law copyright infringement. See 3 NimMer, supra note 1 , at $\$ 13.05$ n.2. Since statutory protection now arises at creation, 17 U.S.C. 302 (Supp. III 1979), the fair use defense may be available prior to publication. See, however, S. REP. No. 473, 94th Cong., 1st Sess. 64 (1975):

The applicability of the fair use doctrine to unpublished works is narrowly limited since, although the work is unavailable, this is the result of a deliberate choice on the part of the copyright owner. Under 
or any further publication. ${ }^{54}$ An unconsented use may have little economic impact on an author's rights, but may nevertheless significantly affect his other interests; since the protection of an author's privacy and control may be as important as economic incentives, a court cannot be guided solely by economic interests when judging fair use.

Another difficulty with relying too heavily upon the effect factor arises from certain generally accepted fair uses, such as criticism and comment, that often have the effect or intention of diminishing the value of the work being reviewed. Excessive borrowing is only one wrong among many, such as libel, which may be committed by a reviewer. Of course, those wrongs are compensable on other grounds. The point, however, is that we sometimes allow an author's work to be harmed when other societal interests that are thought to be of greater importance are served. As noted, the foundational goals of copyright protection are not always achieved by the enforcement of private rights. An unauthorized use of an appropriate character may be deemed fair because it serves public welfare objectives to which the copyright owner's rights should yield, regardless of the harm.

Finally; giving greatest weight to the effect test often causes a court to excuse an unauthorized use after finding that the value of the original work was enhanced rather than harmed. ${ }^{55}$ Unfortunately, the new Copyright Act invites this type of assessment with its indiscriminate statement that the effect ${ }^{56}$ of a use on the value of a work must be considered when determining whether a fair use has occurred. Whether a work is enhanced is perhaps an issue to be considered when assessing damages, but the concept has no place in considering whether an infringement has occurred or a use is fair. A fair use is an uncontrolled use, and absent a countervailing public interest in favor of publication, a second user's unilateral decision that an author's work deserves exposure should not be excused because the author has benefited economically.

\section{Recent Fair Use Developments}

Decisions in recent fair use cases share a general tendency to reach a correct conclusion on incorrect grounds. Codification of the fair use factors has not resulted in more careful analysis by the courts. Instead, continued reliance by the courts on the effect factor has produced poorly founded opinions unfaithful to the adaptability required by the fair use doctrine.

The case of Italian Book Corp. v. American Broadcasting Cos., ${ }^{57}$ while a fine example of infringement defense work, illustrates the difficulties resulting from a court's requiring proof of actual harm to overcome a fair use defense. A band on a parade float performing plaintiff's song was filmed by $\mathrm{ABC}$ as part of its coverage of a

ordinary circumstances the copyright owner's 'right of first publication' would outweigh any needs of reproduction for classroom purposes.

54. These rights are subject to compulsory licenses for secondary transmission by cable television systems, 17 U.S.C. $\$ 111$ (d) (Supp. III 1979); sound recordings, id. $\S 115$; and public performances in jukeboxes, id. $\S 116(\mathrm{~b})$.

55. See, e.g., Mura v. Columbia Broadcasting Sys., Inc., 245 F. Supp. 587, 590 (S.D.N.Y. 1965).

56. 17 U.S.C. $\$ 107$ (Supp. III 1979).

57. 458 F. Supp. 65 (S.D.N.Y. 1978). 
well-known Italian celebration. The song was recorded and later broadcast with the film report on an $A B C$ news program. Plaintiff brought suit claiming copyright infringement and $\mathrm{ABC}$ defended on the basis of fair use.

Plaintiff made what turned out to be a major strategic error: it stipulated that it did not suffer any actual harm because of ABC's use. Although refusing to do so may not have saved plaintiff's claim, the court found such a stipulation to be critical to defendant's fair use defense, concluding that plaintiff's failure to prove loss of profit or an adverse effect on the song's value, sales, or market entitled ABC to a judgment.

The court's decision may have been correct, but its emphasis on plaintiff's economic injury was misplaced. The most important fair use factor excusing ABC's unauthorized use was the character and purpose of its use, not the absence of actual harm to the plaintiff. The court noted almost parenthetically that the legislative history of section 107 states that "incidental and fortuitous reproduction, in a newsreel or broadcast, of a work located in the scene of an event being reported"58 constitutes fair use. Because its attention was focused on plaintiff's failure to prove its injury, ${ }^{59}$ however, the court strained to prove the absence of a harmful effect. For example, the court stated that the parties were not competitors, nor did ABC's use compete with an intended use by the plaintiff. However, the only relevant competition for purposes of fair use analysis, this author submits, is that between uses, not users. Moreover, television broadcast and synchronization rights, the kind of rights exploited by $\mathrm{ABC}$, are among the most valuable music rights a publisher owns.

The case Bruzzone v. Miller Brewing Co. ${ }^{60}$ is another example of a correct outcome based upon a misreading of the effect factor. Plaintiff's market research company used selected frames from defendant's television commercials in questionnaires mailed to over one thousand households to test the commercials' effectiveness and to discover and analyze consumer and advertising trends. Plaintiff used the words and dialogue of the commercials, but otherwise his use was

58. Id. at 71 .

59. Although the court found authority for its approach to the harm issue, the result of each case supporting its position could have been reached on the basis of other factors. In Rosemont Enterprises, Inc. v. Random House, Inc., 366 F.2d 303, 306 (2d Cir. 1966), cert. denied, 385 U.S. 1009 (1967), for example, the defendant's borrowing from prior magazine articles for a biography of Howard Hughes was de minimus. The court also noted the plaintiff's apparent bad faith in bringing the lawsuit. 366 F.2d at 305 . In Time, Inc. v. Bernard Geis Assocs., 293 F. Supp. 130, 146 (S.D.N.Y. 1968), the court rejected as speculative plaintiff's claim that defendant's reprinting of selected frames from a film depiciting the assassination of President Kennedy harmed potential uses of the film. The subject matter of this case, however, was of overwhelming public interest and importance, and the court also noted the defendant's good faith use was not solely for his own benefit. In Mura v. Columbia Broadcasting Sys., Inc., 245 F. Supp. 587, 590 (S.D.N.Y. 1965), a hand puppet was used during a children's television program, a use for which its creator would legitimately expect compensation. Although the court found the defendant's use beneficially affected the plaintiff and was therefore permissible, the use could also be excused as de minimus. Finally, the case of Meeropol v. Nizer, 560 F.2d 1061, 1071 (2d Cir. 1977), cert. denied, 434 U.S. 1013 (1978), does not support an actual harm approach to fair use. That opinion reversed dismissal of a copyright claim when, in response to the defendant's fair use defense, the plaintiffs raised a triable issue whether they had incurred actual damages. In holding that the plaintiffs had a right to proceed to trial, the court did not conclude that the absence of such damage would sustain defendant's fair use defense.

60. 202 U.S.P.Q. 809 (N.D. Cal. 1979). 
fragmentary, amounting to less than one percent of a commercial's frames. He omitted all brand names, color, action, and music. ${ }^{61}$ The results of these tests were then sold by plaintiff to the trade for his own profit.

In plaintiff's declaratory judgment action, the court gave greatest weight in its fair use analysis to the effect plaintiff's use had on the value of the infringed commercials. Since plaintiff's use had a different purpose, occurred after the commercials had been exploited effectively, and did not compete in the same market, the court was unable to see how any foreseeable use Miller might make of its commercials was supplanted. Although the opinion correctly noted that deriving a profit from use does not render that use unfair, ${ }^{62}$ it seemed to unnecessarily adopt a broadly worded per se rule of fair use relating to the harm issue. The court stated that " $[w]$ here subsequent use of a protected work is not in competiton with the copyrighted use, and no showing is made that such subsequent use lessens the value of the copyrighted work, the fair use defense is sustained."63 The fair use doctrine should not be subject to mechanical characterization by such shorthand rules. While Bruzzone decision may be correct, its applicability is limited by language tending to weigh the effect a use has on on original work too heavily.

The case of Iowa State University Research Foundation, Inc. v. American Broadcasting Cos., ${ }^{64}$ presents a better reasoned discussion of the harm concept in fair use and demonstrates the doctrine's unavailability to a bad faith unauthorized user. ${ }^{65}$ Without permission, $\mathrm{ABC}$ broadcast portions of a film biography of a champion wrestler produced by one of the plaintiff's students after initial negotiations with the student to use the film ended inconclusively. ABC first denied its use, but when sued, defended on the basis that its use was fair.

Apparently angered by the bad faith conduct of $A B C$, the district court rejected ABC's fair use defense on the basis that $A B C$ had notice that the copyright holder expected payment for a broadcast use of the film and that $A B C$ was able to pay such a fee. Were it not for the bad faith conduct of $A B C$, the opinion might have had the twin effect of adding ability to pay to the fair use calculus and elevating the otherwise legally gratuitous deterrent legends often placed on a work warning potential users that payment for a use is expected by the owner. Although not expressed in such words, the opinion more legitimately appears to propose that a user's "unclean hands" preclude the fair use defense. 66

61. Application of the substantiality test may be irrelevant for video works. See, e.g., Timberg, $A$ Modemized Fair Use Code For The Electronic As Well As the Gulenberg Age, 75 Nw. U. L. REv. 193, 219 (1980).

62. See, e.g., Rosemont Enterprises, Inc. v. Random House, Inc., 366 F.2d 303, 307 (2d Cir. 1966), cert. denied, 385 U.S. 1009 (1967) ("[W]e conclude that whether an author or publisher has a commercial motive or writes in a popular style is irrelevant to a determination of whether a particular use of copyrighted material in a work which offers some benefit to the public constitutes a fair use.") This holding of the Bruzzone court has been criticized as "bankrupting" the commercial versus nonprofit educational purpose doctrine of fair use. See Timberg, supra note 61 , at 220.

63. 202 U.S.P.Q. at 812 . This language is from Italian Book Corp. v. American Broadcasting Cos., 458 F. Supp. 65 (S.D.N.Y. 1978) at 70.

64. 463 F. Supp. 902 (S.D.N.Y. 1978), affd, 621 F.2d 57 (2d Cir. 1980).

65. Perhaps the best reasoned of recent fair use cases is Roy Export Co. v. Columbia Broadcasting Sys., Inc., 503 F. Supp. 1137 (S.D.N.Y. 1980), involving the unauthorized use of a compilation of Charlie Chaplin films for a retrospective tribute following his death in 1977.

66. "Fair use presupposes 'good faith and fair dealing.' " Time, Inc. v. Bernard Geis Assocs., 293 F. 
Affirming the district court's opinion, ${ }^{67}$ the Second Circuit evaluated ABC's fair use argument along the more common lines recognized in section 107, but found it unpersuasive. ${ }^{68}$ The court rejected ABC's argument that the public benefit gained by broadcasting the life history of an important sports figure excused $A B C$ 's failure to gain plaintiff's permission to use its film. While noting that $A B C$, under the rule in the Second Circuit, was free to use any facts revealed in plaintiff's film, use of the film itself was improper: "The fair use doctrine is not a license for corporate theft, empowering a court to ignore a copyright whenever it determines the underlying work contains material of possible public importance." 69 The court also found that ABC's commercial use weighed against finding the character of its use fair and that its inequitable conduct was important in denying the fair use defense.

The Second Circuit's opinion is recommended for its discussion of the effect $A B C$ 's use had on the market value of plaintiff's film. Despite evidence that the value of plaintiff's film may have been enhanced by ABC's use, the court found that the use fulfilled a potential function of the film-sale for broadcasting during the 1972 Olympics. The court, viewing fair use as one that supplements rather than supplants a work's actual or potential use, found that the plaintiff's television broadcasting rights had been usurped. ${ }^{70}$

The court's opinion is also recommended for its recognition that noneconomic harms are part of the fair use analysis. The court noted that the plaintiff's "copyright entitled it to attempt to exploit the commercial market controlled by ABC, and, if it could not, to withhold permission to use the film in that market." $" 1$ Since the right of control is part of copyright protection's foundation, the harm suffered by its violation should be redressed regardless of the difficulty of gauging the extent of injury.

Perhaps the most significant recent decision discussing the issue of fair use is Universal City Studios, Inc. v. Sony Corporation of America. ${ }^{72}$ In a contest reminiscent of earlier struggles between the motion picture and television industries, ${ }^{73}$ plaintiffs, producers of programming used for television broadcast, brought suit to halt offthe-air videotape recording of their programs. They claimed that the practice was a copyright infringement which exhausted interest in reruns of their programs and

Supp. 130, 146 (S.D.N.Y. 1968). See generally Mitchell Bros. Film Group v. Cinema Adult Theater, 604 F.2d 852, 863-65 (5th Cir. 1979), cert. denied, 445 U.S. 917 (1980).

67. 621 F.2d 57 (2d Cir. 1980).

68. The court's opinion on plaintiff's damages is found at 475 F. Supp. 78 (S.D.N.Y. 1979). This decision was not appealed by the defendant.

69. 621 F.2d at 61 .

70. At one point the court referred somewhat confusingly to the function test in connection with the nature of the copyrighted work, perhaps as a result of the manner in which it was raised by the defendant. $621 \mathrm{~F} .2 \mathrm{~d}$ at 61 . Although this factor interacts with the issue of harm by helping determine a work's legitimate uses, its independent significance lies in providing for an examination of the availability of and the relative public need to receive the information controlled by the copyright. See generally 3 NimMER, supra note 1,8 13.05[A][2].

71. 621 F.2d at 62 [emphasis added].

72. 480 F. Supp. 429 (C.D. Cal. 1979), rev'd in part and affd in part, 659 F.2d 963 (9th Cir. 1981).

73. See, e.g. , Benny v. Loew's, Inc., 239 F.2d 532 (9th Cir. 1956), affd per curiam by an equally divided court sub nom. Columbia Broadcasting Sys. v. Loew's Inc., 356 U.S. 43 (1958); Columbia Pictures Corp. v. National Broadcasting Co., 137 F. Supp. 348 (S.D. Cal. 1955). 
fragmented the live television audience. Defendants included manufacturers, sellers, and one individual owner of videotape recorders. The district court found that home use recording was not a copyright infringement based on both the legislative history of the 1976 Copyright Act and the fair use doctrine under the 1909 and 1976 Copyright Acts. The Ninth Circuit, however, reversed in part and affirmed in part and remanded the case for further proceedings. ${ }^{74}$

The district court, in a lengthy and carefully considered opinion, first sketched the entertainment industry interests and practices underlying the struggle to accommodate new video technology in new contexts. Despite the absence of any express statutory provision withdrawing protection for audiovisual works in the home recording area, the court then found Congressional intent to exclude home use recording from the scope of copyright protection in the legislative history of the sound recording amendment to the 1909 Act, ${ }^{75}$ which had extended copyright protection to sound recordings and was merged into the 1976 Act. The district court cited the following from the House Report accompanying the 1971 amendment:

Specifically, it is not the intention of the Committee to restrain the home recording, from broadcasts or from tapes or records, of recorded performances, where the home recording is for private use and with no purpose of reproducing or otherwise capitalizing commercially on it. This practice is common and unrestrained today, and the record producers and performers would be in no different position from that of the owners of copyright in recorded musical compositions over the past [twenty] years. ${ }^{76}$

This intent, together with the consistent position of the Copyright Office during the period of legislative revision that home use recording was not an infringement, ${ }^{77}$ convinced the court that the accused activity was not meant to be prohibited by the 1976 Copyright Act.

The Ninth Circuit reversed the district court on this point, holding essentially that the court's search of legislative history sought to answer the wrong question. The proper inquiry, the court held, was whether Congress intended to withdraw, rather than afford, protection for video recordings. This view was compelled, the court argued, by simple statutory construction. Section 106 of the Copyright Act sets forth exclusive rights which are made "subject to sections 107 through 118."78 The court, quoting from the legislative history, said, " $[t]$ he approach of the [statute] is to set forth the copyright owner's exclusive rights in broad terms in Section 106, and then to provide various limitations, qualifications or exemptions in the 12 sections that follow."79 After examining the Copyright Act and the legislative history from this perspective, the court found that an implied home video recording exception to a copyright owner's rights did not exist. ${ }^{80}$

74. 659 F.2d 963 (9th Cir. 1981)

75. Act of October 15, 1971 (P.L. 92-140, 85 Stat. 391) (amending 17 U.S.C. $§ 1$ (1970)) as amended by Act of December 31, 1974 (P.L. 93-573, 88 Stat. 1873).

76. 480 F. Supp. at 444 .

77. Id. at $445-46$

78. 17 U.S.C. $\$ 106$ (Supp. III 1979).

79. H.R. REP. No. 1476, 94th Cong., 2d Sess. 61 (1976), guoted in 659 F.2d at 965

80. The Court's conclusion was based on the fact that audiovisual works and sound recordings are statutorily defined as separate categories of works of authorship, audiovisual works have received special consideration from Congress, and the legislative history of the sound recording amendment addressed the issue of home recording of sound recordings but not video recordings. 659 F,2d at 967-69. 
The court then turned to the defendants' fair use argument. In what is certainly its most important contribution to fair use analysis, the court held that the fair use defense may not be interposed to defend home video recording of broadcast signals. The court's analysis of the applicability of fair use began by distinguishing what it termed a "productive" use of copyrighted material from an "intrinsic" or ordinary use. Fair use, the court found, has always had to do with uses such as those listed in section 107 of the Copyright Act, i.e., uses which examine, explain or transform the copyrighted work in some manner or result in some overall societal benefit greater than the private interests of the copyright owner. These uses the court defined as "productive" uses. Fair use has not, until recently, been applicable to reproductions of a work "in the same mode and for the same purpose the original was first acquired,"81 i.e., home duplication of a video cassette rented or purchased from the copyright owner. Home recording of a television broadcast signal is not a reproduction of a work in the mode in which such work is acquired, but it is a reproduction in the mode in which the work is perceived. Without distinguishing between recordings made from broadcast signals or from tapes, the court concluded that home recording of works from broadcast signals is an intrinsic use, implying that its definition of intrinsic use includes expected uses of a work in media other than as the work is first published. ${ }^{82}$

The most troubling instance of improperly applying the fair use defense to intrinsic uses of a copyrighted work is the case of William $\mathcal{G}^{2}$ Wilkins Co. v. United States ${ }^{83}$ which involved photocopying of scientific and medical journals for researchers. The circuit court distinguished this case on the basis that the Court of Claims was faced there with a "countervailing societal benefit to 'weigh' against the copyright interests of the author"84 which was not found in the present case. While the district court's opinion appeared to similarly reject William $\mathcal{E}^{\circ}$ Wilkins Co. as precedent, the circuit court nevertheless found that the district court, like the court in William $\mathscr{F}$ Wilkins Co. , had held an intrinsic use of audiovisual works to be fair, and thus distorted "the fair use rational to justify an application of the doctrine which, in our opinion, stretches fair use beyond recognition and undermines our traditional reliance on the economic incentives provided to authors by the copyright scheme." 85 The court believed that such a restructuring of our copyright system was a matter for Congress rather than the courts to determine and concluded that "the mass copying of the sort involved in this case precludes an application of fair use." 86

To emphasize the inapplicability of the fair use defense to home taping of video broadcast signals, the court next addressed the district court's analysis of the four fair use factors set forth in the Copyright Act and rejected its analysis of each.

The district court's discussion of plaintiffs' fair use claim began well enough by

81. L. Seltzer, Exemptions ANd Fair USE in Copyright 24, quoted in 659 F.2d at 970.

82. The circuit court accepted that "the copies made by home video recording are used for the same purpose as the original. . . " 659 F.2d at 974.

83. 487 F.2d 1345 (Ct. Cl. 1973), affd by an equally divided court, 420 U.S. 376 (1975).

84. 659 F.2d at 971 .

85. Id. at 970 .

86. Id. at 972 . 
correctly distinguishing determination of harm for purposes of damages from the harm concept in fair use. The court stated that "the issue of harm is important in this lawsuit for three determinations: (1) whether the use is fair use, (2) whether an injunction is appropriate, and (3) assuming infringement, what the damages are. Actual harm may not be essential to any of these three determinations."87

The court went on, however, to relate the effect issue to both the nature of the copied material and the purpose and character of borrower's use. For example, the court found that the material was by nature a free offering to the public. Since the plaintiffs were not directly compensated by home viewers, the court believed that the harm caused by their copying was hypothetical. The court was unconvinced that off-the-air home taping and the resulting increased viewer control of broadcasting signals caused more than speculative, and therefore unprotectable, harm. The court also found that the character of the home viewers' use was private and noncommercial and therefore less likely to cause harm to plaintiffs.

The circuit court rejected this reasoning on several grounds. Fair use, the court noted, contrasts commercial with nonprofit educational rather than noncommercial purposes, and it was clear that "the copying of entertainment works for convenience does not fall within the [non-profit educational] category." 88 The court also found that "there seems to be some indication that the scope of fair use is greater when informational type works, as opposed to more creative products, are involved." 89 Since the nature of plaintiffs' works was entertainment, the fair use privilege, the court believed, was accordingly narrowed. The fact that the accused copying was done by people who had received the broadcast signal free was deemed irrelevant for fair use analysis. The court also believed that the privacy issue more appropriately affected the nature of relief that might be fashioned for infringement.

In considering the substantiality of the borrowing, which in this case was the entire work, the district court had rejected the Ninth Circuit rule (stated in Walt Disney Productions v. Air Pirates ${ }^{90}$ ) that excessive copying precludes fair use. The district court found that, since the plaintiffs failed to prove their injury, the defendants' use was fair. The circuit court found the district court's reasoning "completely wrong." 91 The court did not address the district court's rejection of what amounts to a per se substantiality rule in the Ninth Circuit, but held that substantiality should be considered among fair use factors whether or not harm is shown. The court next held that the district court further erred by failing to recognize the potential harm caused plaintiff by home video recording. The court believed the district court imposed on the plaintiff an improper burden of proving actual damages resulting from home video recording and gave insufficient attention to the cumulative effect such recording had on copyrighted works.

This author agrees with the Ninth Circuit opinion that home video recording

87. 480 F. Supp. at 451 .

88. 659 F.2d at 972 .

89. Id.

90. 581 F.2d 751 (9th Cir. 1978), cert. denied, 439 U.S. 1132 (1979).

91. 659 F.2d at 973 . 
cannot be justified on fair use grounds. Compensation for use should not be diminished merely because that use is meant to be privately enjoyed. The privacy of the use meant that only the home viewers doing the video recording profited from the use. Further this author believes that the entertainment nature of plaintiffs' work legitmately contemplated exploitation via prerecorded sight and sound devices such as videocassettes, the sale or rental of which was harmed by home recording. This author believes a legitimate distinction cannot be drawn, as the district court did, between recording a broadcast signal as received over-the-air and recording that same signal when brought into the home via cable as an imported signal or for improved reception. The district court's focus on the destruction of the free public broadcasting market for plaintiffs' material by home video recording ignored the certain effect such recording has on the market for prerecorded sight and sound devices and video signal systems for which a viewer pays a fee. Home use of material such as plaintiffs' is rapidly increasing and, as distribution improves, could potentially replace theatrical release as the means of first exploitation of such material. Home video recording allows an audience an enhanced unauthorized use of plaintiffs' material for the very entertainment purposes such material was created. A function of that material therefore seems clearly fulfilled and should be protected.

The Ninth Circuit remanded the case with instructions that the district court fashion appropriate relief for the plaintiffs. The resolution of this issue may come from Congress, however, rather than the courts. Regulating home video recording would be intrusive and uneconomical and in the end practically impossible. This author believes the only appropriate regulatory scheme is a copyright royalty calculated as a percentage of the retail price of blank video tape. This royalty could be collected and distributed by an agency similar to the American Society of Composers, Authors and Publishers and Broadcast Music, Inc., the agencies which enforce music composers' performance rights. As of this writing, however, several bills have been introduced to undo the Ninth Circuit decision. ${ }^{92}$ It is this author's belief that Congress ultimately will provide the resolution of this dispute by not disturbing the practice of home taping but requiring that those who engage in the practice reward through an indirect royalty scheme appropriate copyright owners.

\section{III}

\section{PARODY}

\section{A. Background of Parody}

Parody, while subject to its own rules, is encompassed by the fair use doctrine as a form of comment and criticism. ${ }^{93}$ The success of a parody depends upon its

92. S. 1758, 97th Cong., 1st Sess. (1981); H.R. 4783, 97th Cong., 1st Sess. (1981); H.R. 4794, 97th Cong. 1st Sess. (1981); H.R. 4808, 97th Cong., 1st Sess. (1981).

93. Parody defenses have been raised in trademark infringement actions but have met with limited success. The fundamental issue in most trademark infringement actions is whether an accused mark is likely to cause confusion, mistake or deception as to the source or sponsorship of goods or services. 15 U.S.C. § 1114(1) (1976). If such a likelihood exists, or if actual intent to pass one's products off as another's is shown, an infringement is held to have occurred. See generally 2 T. MCCARTHY, TRADEMARKS AND 
perceived relation to a familiar object, person or work. Without a notion of the thing being lampooned, comprehension of the parodist's point of view is lost, and the parody fails. The conflict between a parodist's need to borrow and a copyright holder's right to prevent, and perhaps reluctance to authorize, such borrowing is immediately apparent. This conflict has occurred, however, only in comparatively recent cases.

The history of parody and fair use may be generally summarized in three cases. The first discussion appears in the case of Benny $v$. Loew's, Inc., ${ }^{94}$ which involved a television parody by Jack Benny of the motion picture Gaslight. The Ninth Circuit, after discussing the history of fair use and parody, adopted a quantitative view of the parody defense, essentially equating it with insubstantial similarity: "[T] he issue becomes first one of fact, i.e., what was taken and how substantial was the taking; and if it is determined that there was a substantial taking, infringement exists."95 Finding Benny's taking to be substantial, the court upheld an injunction preventing further broadcast of the parody. The related case of Columbia Pictures Corp. v. National Broadcasting Co. ${ }^{96}$ introduced the "recall or conjure up" test, which permitted the parodist to borrow from an original work as needed to link conceptually the parodist's work to the work being copied. Although this test remained essentially quantitative, it represented initial recognition that the parodist required a somewhat greater freedom to borrow if his function as a critic or commentator was to be effective.

The Second Circuit, in Berlin v. E.C. Publications, Inc., ${ }^{97}$ subsequently endorsed the "recall or conjure up" test, but brought the parody defense more properly within the scope of the fair use doctrine. The court found that Mad Magazine's parodies of plaintiff's songs had "neither the intent nor the effect of fulfilling the demand for the original,"98 and were, therefore, permissible. Although the court apparently viewed the "conjure up" test as limiting the amount a parodist could

UNFAIR COMPETITION, ch. 23 (1973). The basic purposes of trademark laws are twofold: to protect both (1) the public interest in full and honest disclosure of product origin, and (2) the trademark owner's investment in time, energy and money in presenting to the public his product. See S. REP. No. 1333, 79th Cong., 2d Sess. 2 reprinted in 1946 U.S. CODE CONG. SERv. 1274, 1274. The public interests served by parody generally yield in a conflict to the public and private interests served by trademark laws. See, e.g., Chemical Corp. of America v. Anheuser-Busch, Inc., 306 F.2d 433 (5th Cir. 1962); General Electric Co. v. Alumpa Coal Co. 205 U.S.P.Q. 1036 (D. Mass. 1979); Gucci Shops, Inc. v. R.H. Macy and Co., 466 F. Supp. 838 (S.D.N.Y. 1977); Coca-Cola Co. v. Gemini Rising, Inc., 346 F. Supp. 1183 (E.D.N.Y. 1972) The parody defense in trademark cases has only been successful when likelihood of confusion between the parody and the object parodied was not proven. See, e.g., Reddy Communications, Inc., v. Environmental Action, 477 F. Supp. 936 (D.C. 1979); General Mills, Inc. v. Henry Regnery Co., 421 F. Supp. 359 (N.D. Ill. 1976); Girl Scouts of the United States v. Personality Poster Mfg. Co., 304 F. Supp. 1228 (S.D.N.Y. 1969).

94. Loew's Inc. v. Columbia Broadcasting Sys., Inc. 131 F. Supp. 165 (S.D. Cal 1955), affd sub nom., Benny v. Loew's, Inc., 239 F.2d 532 (9th Cir. 1956), affd per curiam by an equally divided court sub nom., Columbia Broadcasting Sys., Inc. v. Loew's, Inc., 356 U.S. 43 (1958).

95. 239 F.2d at 537 (quoting 131 F. Supp. at 183).

96. 137 F. Supp 348 (S.D. Cal. 1955). The cases were related in that they were decided close in time by the same district court judge.

97. 329 F.2d 541, 545 (2d Cir. 1964), cert. denied, 379 U.S. 822 (1964).

98. Id. at 545. For a parody case where demand for the original was found fulfilled see Leo Feist, Inc. v. Song Parodies, Inc., 146 F.2d 400 (2d Cir. 1944). 
borrow, the substantiality measure adopted by Benny was questioned in light of the social value offered by parody.

\section{B. Recent Developments in Parody}

Recent cases concerning parody illustrate both a widening difference in the approaches taken by the Second and Ninth Circuits in evaluating permissible parodies and some confusion in other circuits resulting from this difference. These developments may be traced to the opinion in the case of Walt Disney Productions $v$. Air Pirates. ${ }^{99}$ This copyright infringement action arose when defendants published "a rather bawdy depiction of the Disney characters as active members of a freethinking, promiscuous, drug-ingesting counter-culture."100 Rejecting the defendants' fair use defense because their borrowing exceeded that necessary to "recall or conjure up" the Disney characters being parodied, the Ninth Circuit stated what amounted to a per se substantiality rule: "While other factors in the fair use calculus may not be sufficient by themselves to preclude the fair use defense, this and other courts have accepted the traditional American rule that excessive copying precludes fair use."101 The court viewed Benny as providing a test which set a "threshold that eliminates from the fair use defense copying that is virtually complete or almost verbatim." 102 The court admitted that this test eliminated that taking necessary to make perhaps the "best parody"103 by giving an unchanged work an incongruous context or presentation.

The case of Metro-Goldwyn-Mayer v. Showcase Atlanta Cooperative Productions ${ }^{104}$ is both an example of the confusion born of Air Pirates and a misreading of Benny and Berlin. Owners of the copyrights in the novel and movie Gone With The Wind brought an infringement suit against a musical stage production entitled Scarlet Fever. An undenied substantial similarity between the works was defended on the basis of fair use.

The court's fair use analysis began by noting that parody is protectable under the fair use doctrine because of the social value of "the original perspective of the parodist."105 The court believed that without critical comment, parody functions merely as entertainment undeserving of protection. The court, unlike others which have faced similar questions in the past, ${ }^{106}$ then went on to find that the defendant's work lacked social value deserving of protection because it was inconsistent and inconsequential as a parody. The court's opinion represents the con-

99. 581 F.2d 751 (9th Cir. 1978).

100. Id. at 753 (quoting Note, Parody, Copyrights and the First Amendment, 10 U.S.F.L. REv. 564, 582 (1976))

101. 581 F.2d at 758

102. Id. at 756 .

103. Id. at 758 .

104. 479 F. Supp. 351 (N.D. Ga. 1979).

105. Id. at 357 .

106. "The line between transmission of ideas and mere entertainment is too elusive for this court to draw, if indeed such a line can be drawn at all." Stanley v. Georgia, 394 U.S. 557, 566 (1969). See also Bleistein v. Donaldson Lithographing Co., 188 U.S. 239, 251 (1903) ("It would be a dangerous undertaking for persons trained only to the law to constitute themselves final judges of the worth of pictorial illustrations, outside of the narrowest and the most obvious limits."). Cf. Berlin v. E.C. Publications, Inc., 329 F.2d 541, 545 (2d Cir. 1964), cert. denied, 379 U.S. 822 (1965). 
verse of the Air Pirates opinion, i.e., it is not only the best but also the poor parody which is prohibited. The court sought significance in plaintiff's work but found that its overall effect was unimpressive.

Adopting the Ninth Circuit's view that substantial borrowing precludes the fair use defense, the court went on to find that, assuming defendant's work was a valid parody, its taking nevertheless failed as a fair use because it exceeded that necessary to "recall or conjure up the original." The court's analysis in reaching this conclusion, however, reflected a confusion arising primarily from the $A$ ir Pirates' characterization of Benny as providing a threshold test eliminating nearverbatim copying. The court interpreted the threshold as calling for an initial examination of a parody to determine if the near-verbatim copying prohibited by Benny had occurred. If not, the substantiality of the parody's borrowing would then be measured to determine if it exceeded the "recall or conjure up" Berlin test. Proceeding in this manner, the court found that Scarlet Fever passed the Benny test but failed the Berlin test.

The court's analysis, this author submits, is meaningless since it reversed the proper sequence of questions a court should ask of a parody defense. Rather than a threshold, the amount of taking prohibited by Benny is more properly characterized as the point of fair use termination. A court should begin its parody analysis by allowing the parodist enough to "recall or conjure up" the original and then examine how far past that point the taking has proceeded. The Benny test, if it is to have any independent significance, tells the court when the parodist has gone too far. Unless there exists a range of borrowing between the Benny and the Berlin standards properly reviewable by a court, the Metro-Goldwyn-Mayer court's fair use conclusion has no logical foundation.

Having found the defendant's taking excessive, ${ }^{107}$ the Metro-Goldwyn-Mayer court next addressed the issue of the effect defendant's use had on plaintiff's work. Rejecting defendant's argument that its parody enhanced the value of the novel and film, the court found, despite the previous failure of a stage adaptation of Gone With The Wind, that Scarlet Fever fulfilled potential derivative uses of the original. The court reasoned that since the overall function of Gone With The Wind was to entertain, and that since Scarlet Fever failed as anything other than entertainment, defendant's use fulfilled both real and potential functions of, and therefore harmed, the original work. This approach to the effect factor is as expansive as one may reasonably expect from a court and is welcome recognition that the speculative nature of potential future uses of a work does not bar protection for those uses.

The case of Elsmere Music, Inc. v. National Broadcasting Co. ${ }^{108}$ illustrates the Second Circuit's differing approach to determining permissible parody uses. Although, as discussed earlier, the district court dismissed NBC's de minimus

107. 479 F. Supp. at 360. The Metro-Coldwyn-Mayer court also noted the invalidity of defendant's parody for failure to take as the object of its parody those portions of Gone With The Wind which it paralleled, again citing Air Pirates, which, in a footnote, 581 F.2d at $758 \mathrm{n} .15$, stated that the need to conjure up the Disney characters would be "reduced if not eliminated" if they were not also an object of the parody.

108. 482 F. Supp. 741 (S.D.N.Y.), affd 623 F.2d 252 (2d Cir. 1980). 
defense, ${ }^{109}$ it concluded that the use of plaintiff's "I Love New York" advertising jingle in an NBC Saturday Night Live comedy sketch was a fair parody.

To reach this conclusion, the court was required to deal with the plaintiff's assertion that NBC's parody was invalid because it failed to parody plaintiff's song itself or the campaign with which it was used. Plaintiff cited both $M C A$, Inc. $v$. Wilson ${ }^{110}$ and Walt Disney Productions v. Mature Pictures Corp. ${ }^{111}$ as authority for this rule. The court found, however, that although the song was commissioned by the State of New York, its extensive use in connection with New York City created a strong identification between the city and the song which precluded plaintiff's argument. More significantly, the court went on to expressly disagree with both $M C A$ and Walt Disney and conclude that the subject matter of a valid parody need not be the work copied or something strongly identified with a copied work. The court stated, "[T]he issue to be resolved by a court is whether the use in question is a valid satire or parody, and not whether it is a parody of the copied song itself."'112

The court reasoned instead that section 107's fair use criteria and Berlin's holding that no infringement occurs when a parody has "neither the intent nor the effect of fulfilling the demand for the original" more properly test a parody claim. ${ }^{113}$ The district court's rejection of the unnecessarily restrictive $M C A$ and Walt Disney holdings, together with its more flexible and accommodating application of the fair use factors to parody claims, was evidence of an alternative approach to the Ninth Circuit's rather mechanical parody analysis.

The Second Circuit's one-paragraph opinion ${ }^{114}$ affirming the district court's judgment for the defendant made clear the divergent views that the Second and Ninth Circuits have taken. Concluding that "in today's world of often unrelieved solemnity, copyright law should be hospitable to the humor of parody,"115 the court stated in the opinion's only footnote:

[W] note that the concept of "conjuring up" an original came into the copyright law not as a limitation on how much of an original may be used, but as a recognition that a parody frequently needs to be more than a fleeting evocation of an original in order to make its humorous point. Columbia Pictures Corp. v. National Broadcasting Co., 137 F. Supp. 348 (S.D. Cal. 1955). A parody is entitled at least to conjure up the original. Even more extensive use would still be fair use, provided the parody builds upon the original, using the original as a known element of modern culture and contributing something new for humorous effect or commentary. ${ }^{116}$

Regardless of one's opinion of the court's view of the world, it should be clear that its approach to parody analysis correctly reconciles the leading parody deci-

109. See notes 5-6 and accompanying text supra.

110. 425 F. Supp. 443 (S.D.N.Y. 1976).

111. 389 F. Supp. 1397 (S.D.N.Y. 1975)

112. 482 F. Supp. at 746.

113. The court found, without much discussion, that defendant's use did not affect the value of plaintiff's song. Apparently ignoring for a moment the interests and sensibilities motivating plaintiff's lawsuit, the court simultaneously justified its finding and dismayed those authors preferring tribute of a more tangible form with the statement that "[j]ust as imitation may be the sincerest form of flattery, parody is an acknowledgement of the importance of the thing parodied." 482 F. Supp. at 747.

114. 623 F.2d 252 (2d Cir. 1980).

115. Id. at 253 .

116. Id. at 253 n.l. 
sions and permits the flexibility necessary for the proper application of the fair use doctrine to parody claims. To continue the Ninth Circuit's view that the "conjure up" test is a limitation not only leaves the Benny decision without application, but, more importantly, tends to diminish our full enjoyment of the parodist's unique contribution to our insight and understanding. ${ }^{117}$

\section{IV}

\section{FIRST AMENDMENT}

The first amendment defense to copyright infringement actions is of comparatively recent origin. ${ }^{118}$ At issue is the apparent paradox of a constitutionally based statute authorizing the abridgement of a constitutionally protected right. The traditional expression/idea dichotomy in copyright theory ${ }^{119}$ provides some resolution to the seemingly irreconcilable circumstance. That is, since an idea is not copyrightable, the first amendment right to express that idea in one's own fashion should be uninhibited. In reality the resolution is not so clearly founded, but the balance struck by the expression/idea dichotomy, as expressed by Nimmer, seems appropriate:

[I]t appears that the idea-expression line represents an acceptable definitional balance as between copyright and free speech interests. In some degree it encroaches upon freedom of speech in that it abridges the right to reproduce the "expression" of others, but this is justified by the greater public good in the copyright encouragement of creative works. In some degree it encroaches upon the author's right to control his works in that it renders his "ideas" per se unprotectable, but this is justified by the greater public need for free access to ideas as a part of the democratic dialogue. ${ }^{120}$

Despite much attention from the courts and commentators, the first amendment defense has been successfully interposed in only one decision, Triangle Publications 0. Knight-Ridder Newspapers. ${ }^{121}$ This decision, however, was recently affirmed

117. The parody defense was also raised recently in Dallas Cowboys Cheerleaders, Inc. v. Scoreboard Poster, Inc., 600 F.2d 1184 (5th Cir. 1979). The defendant marketed a poster featuring a photograph of former Dallas Cowboys cheerleaders posed partially nude in uniforms nearly identical to those worn by the official cheerleaders and arranged in a formation similar to that used in a popular poster of plaintiff's cheerleaders published a year earlier. The Fifth Circuit's discussion of defendant's fair use claim was limited by the status of the case as presented for review. The court cited both the Benny and Air Pirates cases as examples of situations when the parody defense was unsuccessful, but did not find in the record before it the required proofs to determine that the preliminary injunction against the defendant was improperly issued. Stating that defendant's parody defense might ultimately prevail when fully tried, the court noted "[n]othing beyond an unelaborated invocation of the term 'parody' was ever put before the district court, and we cannot fault the court if it found the simple allusion to the concept of parody insufficient to shift the calculus of probabilities in the defendant's favor." Id. at 1188 .

The parody defense was also recently raised in D.C. Comics, Inc., v. Crazy Eddie, Inc., 205 U.S.P.Q. 1177 (S.D.N.Y. 1979), in which the court found that defendant's television advertisements for his "home entertainment" business infringed plaintiff's copyrights in the Superman character as used in filmed television productions. Although the court recognized that a parodist has a greater ability to borrow a copyrighted work, it easily dismissed defendant's claim by finding that his use was not parody. "This is not a case of fair use, but one of unjustifiable appropriation of copyrighted material for personal profit." Id. at 1178 .

118. See Goldstein, Copyright and the First Amendment, 70 Colum. L. Rev. 983 (1970); Nimmer, Does Copyright Abridge the First Amendment Guarantees of Free Speech and Press.', 17 U.C.L.A. L. REV. 1180 (1970).

119. 17 U.S.C. $\$ 102$ (b) (Supp. III 1979). See 1 NimMER, supra note 1, § 2.03[D].

120. 1 NIMMER, supra note $1, \S 1.10[\mathrm{~B}]$ at $1-76$ and 1-77.

121. 445 F. Supp. 875 (S.D. Fla. 1978). 
by a Fifth Circuit ${ }^{122}$ split on whether the first amendment issue required or deserved review. ${ }^{123}$

The Triangle case arose when the defendant, in order to introduce its own television programming guide, reproduced the cover of a recent issue of the plaintiff's $T V$ Guide periodical in television and print advertisements for its new programming guide. The court adopted what amounts to a per se rule eliminating commercial uses from the fair use doctrine by rejecting the defendant's reading of section 107's phrase "including whether such use is of a commercial nature or is for nonprofit educational purposes" 124 as excluding the type of commercial display in question. The court also rejected the defendant's argument that the purpose of its use, comparative advertising, was a new form of criticism encompassed by the fair use doctrine, noting that the flexibility of the fair use exception was designed to accommodate technological changes in the "means of transmission-not the substance transmitted." 125 The court further found that the purpose of the defendant's use could not be excused as one reasonably contemplated by the plaintiff.

Having dismissed the defendant's fair use defense on the ground of commercial use, the court then concluded that the recent extension of first amendment protection to commercial speech made palpable the theretofore theoretical conflict between copyright and first amendment interests. Accordingly, this conflict needed to be resolved. The court's hasty conclusion, however, that the first amendment was properly at issue, and that it constituted a valid defense, reflected an eagerness to resolve a novel question more than a well-founded examination of the case before it. For example, the court redeemed the defendant's commercial use on constitutional grounds without explaining why the use, if not fair, was nevertheless required by the defendant and constitutionally protected.

On appeal, the Fifth Circuit refused to consider defendant's first amendment defense. Instead, the court concluded that the fair use doctrine excused the disputed use. ${ }^{126}$ The court rejected the district court's per se fair use rule regarding commercial use, finding that the public benefit from truthful comparative advertising balanced the defendant's commercial gain. In reviewing the other statutory fair use factors, the court found that the nature of the plaintiff's work was unimportant for its analysis, but it did conclude that defendant's reproduction of only the cover of the plaintiff's publication was an insignificant use. Of greater concern to the court was the plaintiff's failure to demonstrate that it suffered actual economic harm as a result of the defendant's use. It was principally on this basis that

122. 626 F.2d 1171 (5th Cir. 1980).

123. The opinion has also been the subject of several critical law review articles. See Denicola, Copyright and Free Speech: Constitutional Limitations on the Protection of Expression, 67 CALIF. L. REV. 283 (1979); Note, Copyright Infringement and the First Amendment, 79 Colum. L. REV. 320 (1979); Note, Constitutional Law-Commercial Speech-Copyright and the First Amendment-Triangle Publications, Inc., v. Knight-Ridder Newspapers, Inc., 1979 WISC. L. REV. 242 (1979).

124. 17 U.S.C. $\$ 107$ (Supp. III 1979).

125. 445 F. Supp. at 880 .

126. In a concurring opinion, Judge Tate stated that had the fair use defense not properly excused the defendant's reproduction of the plaintiff's cover, he would agree completely with the district court holding that the first amendment barred plaintiff's relief. $626 \mathrm{~F} .2 \mathrm{~d}$ at 1184 . 
the court concluded the defendant's use was fair, providing another example of the right conclusion founded on the wrong grounds.

The problem in Knight-Ridder, as in Bruzzone, is the determination of the scope of protection to be accorded commercial material having a relatively brief useful life and a correspondingly reduced range of exploitation. The nature of plaintiffs work, rather than being a neutral factor, becomes critical in cases such as these. In a general sense, defendant's use of plaintiff's cover occurred in the precise medium for which the cover was created: print and television advertising. The difference, of course, is that Triangle's cover was created to sell the magazine to which it was affixed, not defendant's product. Moreover, Triangle's cover, while certainly copyrightable, was primarily a functional sales device for which the plaintiff only indirectly received compensation. Triangle's real products and services are the periodical's text and advertising space. Advertising use of the cover provided no revenue except to the extent it maintained or boosted circulation. Although Triangle expected economic reward from the use of its cover, it was created to sell something other than itself. If the nature of plaintiff's work had received more than a cursory examination, the court's fair use analysis would have been more properly focused on whether any actual or potential uses of the cover available to the plaintiff were supplanted by the defendant.

Judge Brown, while concurring with the majority that the defendant's use was fair, provided a lengthy dissent to their refusal to address the first amendment issue. ${ }^{127}$ Citing Wainwright S.E.C., Inc. v. Wall Street Transcript Corp. ${ }^{128}$ Dallas Cowboys Cheerleaders v. Scoreboard Posters, ${ }^{129}$ and Sid $\mathcal{E}^{\circ}$ Marty Kroff Television v. McDonald's Corp. ${ }^{130}$ he first pointed out that the idea/expression dichotomy has generally served to resolve the asserted copyright/free speech tension. He also noted, however, that a legitimate conflict may arise from the use of certain visual works wherein an idea and its expression are merged. Judge Brown believed that in such cases "copyright interest[s] should nearly always prevail over the generally incidental First Amendment concerns."131

The dissent then stated that the district court incorrectly invoked the first amendment as a defense, not only because the fair use doctrine appropriately resolved the matter, but also because the commercial free speech cases relied on by the court were not on point. Judge Brown noted that commercial speech is afforded more limited protection than noncommercial expression, which is itself subject to other interests, and that the comparative advertising undertaken by the defendant could have been accomplished without a copyright violation. More importantly, the dissent made the telling point that neither the district court nor the parties identified the idea which was unalterably bound to plaintiff's expression that defendant needed to express. Since free speech excuses only that borrowing necessary to convey an idea, and there was no explanation of how

127. 626 F.2d at 1178 .

128. 558 F.2d 91 (2d Cir. 1977), cert. denied, 434 U.S. 1014 (1978).

129. 600 F.2d 1184 (5th Cir. 1979).

130. 562 F.2d 1157 (9th Cir. 1977).

131. 626 F.2d at 1182 . 
plaintiff's cover wedded an idea and its expression, the court "doubt[ed] that the First Amendment interests asserted here are in any way significant." 132

The first amendment defense has been inappropriately raised in several other cases. For example, in Dallas Cowboys Cheerleaders, Inc. v. Scoreboard Posters, Inc. ${ }^{133}$ the court, finding it unnecessary to discuss the constitutional problems raised by defendant's first amendment defense, concluded that the claim was meritless, stating that " $[\mathrm{t}]$ the First Amendment is not a license to trammel on legally recognized rights in intellectual property." 134 In Iowa State University Research Foundation, Inc. $v$. The American Broadcasting Co. ${ }^{135}$ ABC's first amendment defense was dealt with by the Second Circuit in a footnote. The court recognized that in certain rare instances "the informational value of . . . [a] . . film cannot be separated from the photographers' expression ... [and therefore] . . both should be in the public domain," 136 but found that the film at issue did not fall within that limited category. In Italian Book Corp. v. American Broadcasting Cos. ${ }^{137}$ the court, having dismissed the complaint on fair use grounds, was not required to reach ABC's first amendment defense. The court offered in a footnote, however, that damage claims and suits to enjoin communications should be distinguished when evaluating a free speech claim:

Where . . a thrust of the suit is to obtain compensation, rather than to restrain communication, recourse to the First Amendment may be inappropriate as well as unnecessary. The copyright owner must be compensated for an infringing use. If the defendant's use is fair and reasonable, no infringement has occurred and no compensation is owing. . . . In the resolution of such claims, the precise office to be performed by the First Amendment is not clear. ${ }^{138}$

In Metro-Goldwyn-Mayer v. Showcase Atlanta. Cooperative Productions, ${ }^{139}$ the defendant's first amendment defense was quickly dismissed by the court's somewhat illogical and irrelevant conclusion that since Scarlet Fever was an invalid parody, it was not entitled to first amendment protection. In Quinto v. Legal Times of Washington, Inc. ${ }^{140}$ the newspaper defendant's claim of first amendment privilege to reprint an article was denied upon the court's finding that the defendant appropriated the plaintiff's expression rather than the newsworthy facts disclosed in the article. Finally, in Dodd, Mead $\mathcal{E}^{\circ}$ Co. v. Lilienthal, ${ }^{141}$ the court rejected the defendant's argument that the first amendment precluded a publisher's infringement action to prevent an author's publication of his own book in contravention of an exclusive publishing contract between the publisher and the author.

The lack of success of the free speech defense will probably not end its use in copyright litigation soon. It is already clear from the cases, however, that the defense is both narrow and unlikely to avail except in certain rare situations.

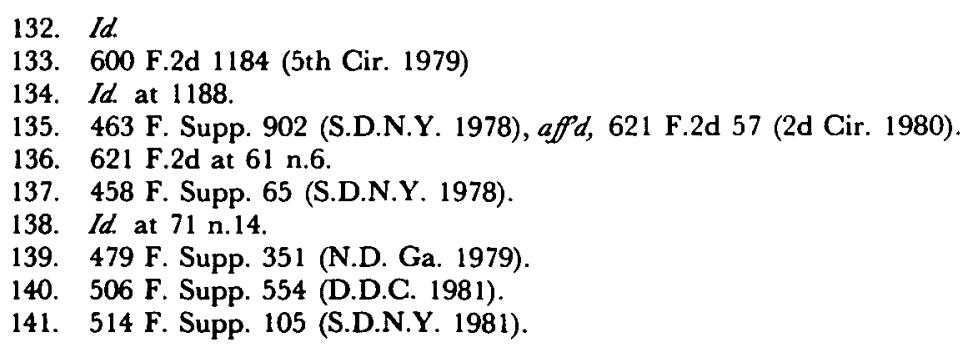




\section{CONCLUSION}

The conflicting principles guiding the reconciliation of copyright infringement claims and defense claims were recognized almost two hundred years ago by Lord Mansfield:

We must take care to guard against two extremes equally prejudicial; the one that men of ability, who have employed their time for the service of the community may not be deprived of their just merits and reward for their ingenuity and labor; the other that the world may not be deprived of improvements nor the progress of the arts be retarded. ${ }^{142}$

While these principles are as valid today as then, our belief in how such principles are best achieved shifts as our values, policies and social conditions change. For example, the Second Circuit's expansion of the parodist's right to borrow in Elsmere Music, Inc. v. National Broadcasting Co., although stated in a somewhat tongue-in-cheek manner, nevertheless reflected its judgment that greater freedom for humor and commentary is needed. New forms of expression and communication reorder our social policies and patterns and produce even greater shifts in the balance between protecting and invading a copyright owner's rights. It is for these reasons that copyright infringement defense cannot be rigidly defined.

142. Sayre v. Moore, 102 Eng. Rep. 139 (1785), quoted in Bevan v. Columbia Broadcasting Sys., Inc., 329 F. Supp. 601, 605 (S.D.N.Y. 1971). 